\title{
Evaluation of Tourism Environmental Carrying Capacity in Diaoshuihu National Forest Park
}

\author{
Yunhe Wang*, Jia Li, Meiqi Zhang \\ College of Chinese Medicine Materials, Jilin Agricultural University, Changchun 130000, China
}

Corresponding Author Email: wangyunhe2015@163.com

https://doi.org/10.18280/ijsdp.150518

Received: 27 January 2020

Accepted: 9 April 2020

\section{Keywords:}

Diaoshuihu National Forest Park $(D N F P)$, tourism environmental carrying capacity (TECC), rural tourism, analytic hierarchy process $(A H P)$

\begin{abstract}
In recent years, rural tourism has become a hot topic in the academia. Many researchers have proposed to alleviate the poverty of farmers and revitalize rural areas through rural tourism. This paper fully quantifies the tourism environmental carrying capacity (TECC) of Diaoshuihu National Forest Park (DNFP), and evaluates the current status of rural tourism near the scenic spot. Four criteria were selected according to the actual situation of the scenic spot. The TECC of the DNFP was evaluated by Pascal's Principle and then through analytic hierarchy process (AHP). Based on the evaluation results, several suggestions were put forward to promote the scenic spot-based rural tourism in and around the DNFP. The results show that the TECC of the DNFP was 6,160 persons, the annual TECC was 985,600 person/year, indicating that the scenic spot is under weak load. The local government is advised to optimize the design and implementation of DNFP-based rural tourism from four aspects: enhancing the integration between scenic spot and nearby villages, rationalizing the income distribution system, training talents for scenic spot-based rural tourism, and stepping up government guidance on rural tourism. The research results provide a reference for similar cases of scenic spot-driven rural tourism.
\end{abstract}

\section{INTRODUCTION}

The tourism environmental carrying capacity (TECC) of a tourist area is measured by the number of tourists whose minimum travel demand can be satisfied without damaging the eco-environment $[1,2]$. It is very meaningful to evaluate the TECC of each tourist area: the evaluation results reflect the trend and weaknesses of scenic spot, highlight the importance of TECC-based service functions, provide scientific basis for rational use of scenic resources, thereby ensuring the sustainable development of scenic spot [3,4]. Currently, there are mature theories and methods for TECC evaluation. However, the TECC evaluation has rarely been applied to rural tourism, not to mention the rural revitalization through scenic spot-driven tourism.

The concept of TECC was created by Matijová et al. [5] in 1963. Later, Zhu et al. [6] divided the TECC into four parts: biophysical capacity, sociocultural capacity, psychological capacity, and management capacity. The earliest TECC research in China appeared in the 1980s. The definition of TECC given by Triyatmo et al. [7] has been widely recognized by domestic scholars. Lerario and Di Turi [8] proposed an intuitive and a controllable concept of TECC, which consists of economic carrying capacity, eco-environmental carrying capacity, psychological carrying capacity, and resource carrying capacity; the four-dimensional TECC concept makes it easy to judge whether the development mode of a scenic space is sustainable. Cupul-Magaña and Rodríguez-Troncoso [9] constructed a mathematical calculation model of tourist capacity, in which the lower bound of TECC is constrained by accommodation, transportation, infrastructure, space and stay time.

Originated in Europe, Rural tourism is highly developed in western Europe and North America. In 1999, Britain put forward the pro-poor tourism (PPT) theory [10], which is well received around the world. Soon, the United Nations (UN) called on countries to promote rural economy and alleviate poverty through tourism. In recent years, many Chinese scholars [11-13] probed deep into the rural revitalization strategy, and provided suggestions for rural development in different regions. As China elevated precision poverty alleviation into a national strategy, more and more scholars have paid attention to poverty alleviation through rural tourism driven by scenic spots. For example, Silva-Pérez et al. [14], Buckley [15], and Raftopoulos [16] explored deep into the scenic spot-driven rural tourism in different regions.

To date, some scholars have elaborated on the scenic spots, location advantages, karst cave composition, biodiversity, and development status of the Diaoshuihu National Forest Park (DNFP) [17]. However, their research has yielded a limited amount of results, and lacks quantitative and qualitative analyses. In the context of rural revitalization, this paper attempts to evaluate the TECC of the DNFP, identify the difficulties in rural tourism of the villages near the DNFP, and prepare the corresponding solutions. The research results provide a reference for similar cases of scenic spot-driven rural tourism.

\section{OVERVIEW OF THE STUDY AREA}

The DNFP (N: $43^{\circ} 19^{\prime} 58^{\prime},-43^{\circ} 24^{\prime} 58^{\prime \prime} ;$ E: $125^{\circ} 45^{\prime} 44^{\prime \prime}$ - 
$\left.125^{\circ} 45^{\prime} 58^{\prime \prime}\right)$ is located $41 \mathrm{~km}$ in the southwest of Shuangyang District, Changchun, the seat of Jilin province. This AAA scenic spot is linked up with downtown Changchun by hardened highways. The scenic spot of the DNFP covers a total area of $4,805.8 \mathrm{hm}^{2}$,

In the DNFP, the negative ions content in the air averages at $45 \mathrm{ions} / \mathrm{cm}^{3}$, peaking at $71 \mathrm{ions} / \mathrm{cm}^{3}$. The zenith point of the park, the $711 \mathrm{~m}$-tall Shenlu Peak, is the tallest peak in Changchun. The scenic spot has a variety of vegetations, including wild vascular plants in 543 species, 22 varieties and 5 subspecies.

Due to its karst landform, the main tourist attractions at the scenic spot are an ice cave and a karst cave. The ice cave boasts the largest ice reserve, the strongest cooling effect, and the greatest depth in northeast China. The karst cave boasts the highest elevation, the largest drop, and the widest area in northeast China [18]. The spatial structure of the DFNP is presented in Figure 1.

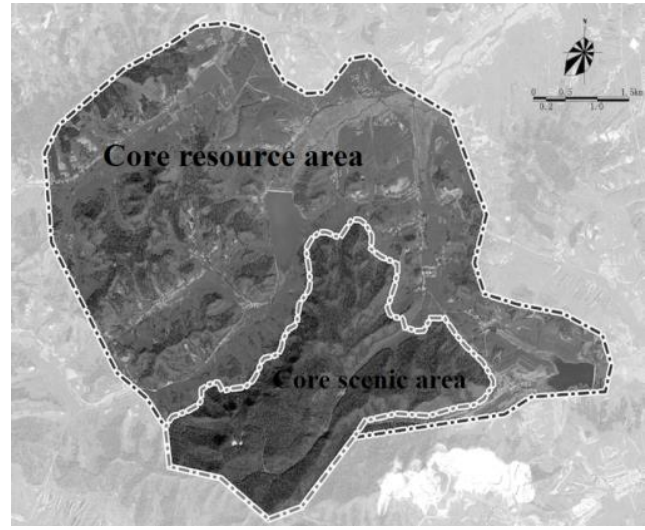

Figure 1. Spatial structure of the DNFP

\section{RESEARCH METHOD AND DATA}

\subsection{Research method}

The basic information of DNFP, tourists, and nearby villagers was collected through field interviews. To collect accurate data, a field survey was carried out on the DNFP, using section timing method. The research team visited the local statistics authority, and conduced field investigation and research, referring to The Yearbook of China Tourism Statistics 2018 and the development status of scenic spots in similar national forest parks [19-22]. The collected data were sorted and screened, leaving only those meeting the development status of the scenic spot. To ensure the reliability of data, the research team visited six administrative villages around the DNFP. A total of 100 villagers were found to engage in rural tourism. Most of them are still living on agritainment, the preliminary form of rural tourism [23].

\subsection{Construction of evaluation index system}

The evaluation index system was constructed in the following steps:

(1) The indices that greatly affect the scenic spot were selected by summarizing the literature related to the study area.

(2) The indices that reflect the unique resources of the DNFP were added to the evaluation index system. To ensure the correctness of the data, the evaluation index system was constructed according to The Reply of the State Forestry Administration on Approving the Establishment of 62 National Forest Parks Including Daxing Gusang (Lin/Chang/Fa (2004) No. 217).

(3) The expression of the evaluation index system was improved by consulting experts in relevant subjects (e.g. human geography and tourism) and referring to the experience of rural tourism development, aiming to accurately reflect the connotation of each index.

\subsection{Data sources}

The revenue and passenger flow of the DNFP were extracted from Zhongqing Shenlu Cultural Tourism Co., Ltd, the contractor of the scenic spot. The data on the alternative layer of the TECC evaluation index system were collected from local statistical yearbooks and field survey. The data on the nearby villages were obtained through field survey and interviews on local villagers.

\subsection{Data analysis}

The TECC evaluation criteria were weighted on yaahp V10.3. Each index was rated by experts engaging in ecology, tourism, and rural tourism. The collected data were analyzed by a parameter table plotted on Excel.

\section{TECC ANALYSIS}

\subsection{Evaluation index system}

The evaluation indices of TECC must be selected according to the specific location and infrastructure of the DNFP [24]. Based on the conceptual model of TECC and Pascal's Principle, the DNFP's TECC was assumed to equal the minimum among natural environmental bearing capacity (NEBC), resource environmental bearing capacity (REBC), economic environmental bearing capacity (EEBC), and social environmental bearing capacity (SEBC):

\section{$\mathrm{TECC}=\mathrm{Min}(\mathrm{NEBC}, \mathrm{REBC}, \mathrm{EEBC}, \mathrm{SEBC})$}

The TECC evaluation index system for the DNFP is displayed in Table 1 below.

The DNFP has relatively strong REBC and tourist psychological capacity (SEBC2). The REBC is higher than that $(5,300$ persons) in Fubao National Forest Park and that (5,530 persons) in Hainan Forest Park; the SEBC2 is also higher than that $(4,355$ person/d) in Fubao National Forest Park and that (3,936 person/d) in Hainan Forest Park [25-29].

The catering standard (EEBC2) and accommodation standard (EEBC3) are relatively weak, because the travel mode in the DNFP is dominated by half-day tour, in which few tourists eat or lodge in the tourist spot.

The carrying capacities of water and power supply facilities (EEBC4-5) are infinite, as both water and power are supplied by the government. The resident psychological capacity (SEBC1) is also infinite, for residents all wish to earn more by attracting more tourists. In addition, the sewage treatment capacity (NEBC3) is infinite, too. The sewage mainly refers to kitchen waste sewage and sanitary sewage. The former is transported to the wastewater treatment plant, while the latter is discharged naturally. 
Table 1. TECC evaluation index system for the DNFP

\begin{tabular}{|c|c|c|c|}
\hline Goal layer & Criteria layer & Alternative layer & $\begin{array}{l}\text { Carrying capacity of each index } \\
\text { (persons) }\end{array}$ \\
\hline \multirow{4}{*}{$\begin{array}{l}\text { TECC } \\
\text { evaluation } \\
\text { index } \\
\text { system for } \\
\text { the DNFP }\end{array}$} & $\begin{array}{c}\text { Natural environmental } \\
\text { bearing capacity (NEBC) }\end{array}$ & $\begin{array}{c}\text { Air quality (NEBC1) } \\
\text { Solid waste treatment capacity (NEBC2) } \\
\text { Sewage treatment capacity (NEBC3) } \\
\end{array}$ & $\begin{array}{c}\mathrm{NEBC} 1=(\mathrm{S} * \mathrm{f} / \mathrm{p})=1,189,237 \\
\mathrm{NEBC} 2=(\mathrm{N} * \mathrm{~S}+\mathrm{H}) / \mathrm{P}=8,400 \\
\mathrm{NEBC} 3=+\infty\end{array}$ \\
\hline & $\begin{array}{l}\text { Resource environmental } \\
\text { bearing capacity (REBC) }\end{array}$ & $\begin{array}{c}\text { Area bearing capacity (REBC1) } \\
\text { Route carrying capacity }(\mathrm{REBC} 2) \\
\end{array}$ & $\begin{array}{c}\mathrm{Dm}=\mathrm{S} / \mathrm{D}=4,805,000 \\
\mathrm{Da}=\mathrm{Dm} * \mathrm{~T} / \mathrm{t}=12,813,333 \\
\mathrm{C}=\mathrm{L} / \mathrm{D} * \mathrm{~T} / \mathrm{t}=5,600\end{array}$ \\
\hline & $\begin{array}{l}\text { Economic environmental } \\
\text { bearing capacity } \\
\text { (EEBC) }\end{array}$ & $\begin{array}{l}\text { Number of parking spaces in scenic spot (EEBC1) } \\
\text { Catering standard (EEBC2) } \\
\text { Accommodation standard (EEBC3) } \\
\text { Water supply facility carrying capacity (EEBC4) } \\
\text { Power supply facility carrying capacity (EEBC5) }\end{array}$ & $\begin{array}{c}\mathrm{EEBC} 1=\sum\left(\mathrm{J} *(\mathrm{~T} / \mathrm{t})^{*} \mathrm{P}\right)=\mathrm{P} * \mathrm{r}=1840 \\
\mathrm{EEBC} 2=\mathrm{F}^{*}(\mathrm{~N} / \mathrm{n}) / \mathrm{f}=240 \\
\mathrm{EEBC} 3=\mathrm{B} *(\mathrm{~T} / \mathrm{t}) / \mathrm{F}=7,500 \\
\mathrm{EEBC} 4=+\infty \\
\mathrm{EEBC} 5=+\infty\end{array}$ \\
\hline & $\begin{array}{l}\text { Social environmental } \\
\text { bearing capacity (SEBC) }\end{array}$ & $\begin{array}{l}\text { Resident psychological capacity (SEBC1) } \\
\text { Tourist psychological capacity (SEBC2) } \\
\text { Staff psychological capacity (SEBC3) }\end{array}$ & $\begin{array}{c}\mathrm{SEBC} 1=\mathrm{A} * \mathrm{~Pa}=+\infty \\
\mathrm{SECC} 2=(\mathrm{A} * \mathrm{~T}) /(\mathrm{P} * \mathrm{t})=2,402,500 \\
\mathrm{SEBC} 3=\mathrm{M} * \mathrm{~F}+\mathrm{N} * \mathrm{E}=4,648\end{array}$ \\
\hline
\end{tabular}

\subsection{The TECC}

Based on the four criteria, the TECC of the DNFP was obtained as TECC $=\mathrm{Min}(\mathrm{NEBC}, \mathrm{REBC}, \mathrm{EEBC}$, $\operatorname{SEBC})=\operatorname{Min}(8,400, \quad 5,600, \quad 240, \quad 4,648)=240($ persons $/ d)$. Obviously, the calculation of the TECC under the Pascal's Principle is rapid and convenient, but overlooks the dynamic changes in the natural and human resources of the scenic spot.

To avoid this defect, the analytic hierarchy analysis (AHP) was introduced to further process the data. The score of each criterion was multiplied with a unique weight, making the TECC more in line with the development of the scenic spot.

\subsubsection{AHP model}

The AHP model of the TECC for the DNFP consists of a goal layer, a criteria layer, and an alternative layer. The indices under each criterion are shown in Figure 2 below.

\subsubsection{Judgement matrix}

The judgement matrix (Table 2) was constructed by the AHP. The results show that the average random consistency index was 0.051 . The consistency ratio was $0.058<0.1$, which meets the consistency standard.

\subsubsection{Weight of each criterion}

As shown in Table 3, the weights of the four criteria, namely, REBC, EEBC, SEBC and NEBC were 24.27\%, 14.39\%, $10.25 \%$, and $51.09 \%$, respectively. The weights were multiplied with the scores of the corresponding criteria to obtain the TECC:

TECC $=8,400 * 51.09 \%+5,600 * 24.27 \%+240 * 14.39 \%+4,648 *$ $10.25 \%=6160($ persons $/ \mathrm{d})$

Each year, the DNFP opens from May $1^{\text {st }}$ to October $7^{\text {th }}$. Therefore, the annual TECC of the scenic spot equals $160 * 6,160=985,600$ (person/year). From 2012 to 2018, the scenic spot received 25,071 persons each year, indicating that the scenic spot is under weak load (Table 4).

There are three main reasons for the weak load state: (1) The current strategy of the scenic spot mainly caters to the residents of Changchun; the tourist flow is small and the source is far from diverse. (2) The karst cave of the DNFP is a tourist resource with a low rate of revisit; most tourists speak highly of the scenery, but will not visit the scenic spot again; this slows down the growth of the number of tourists. (3) The infrastructure in the scenic area is outdated; the supporting facilities are complete but of poor quality; the DNFP has a weak overall competitiveness, compared with other forest parks.

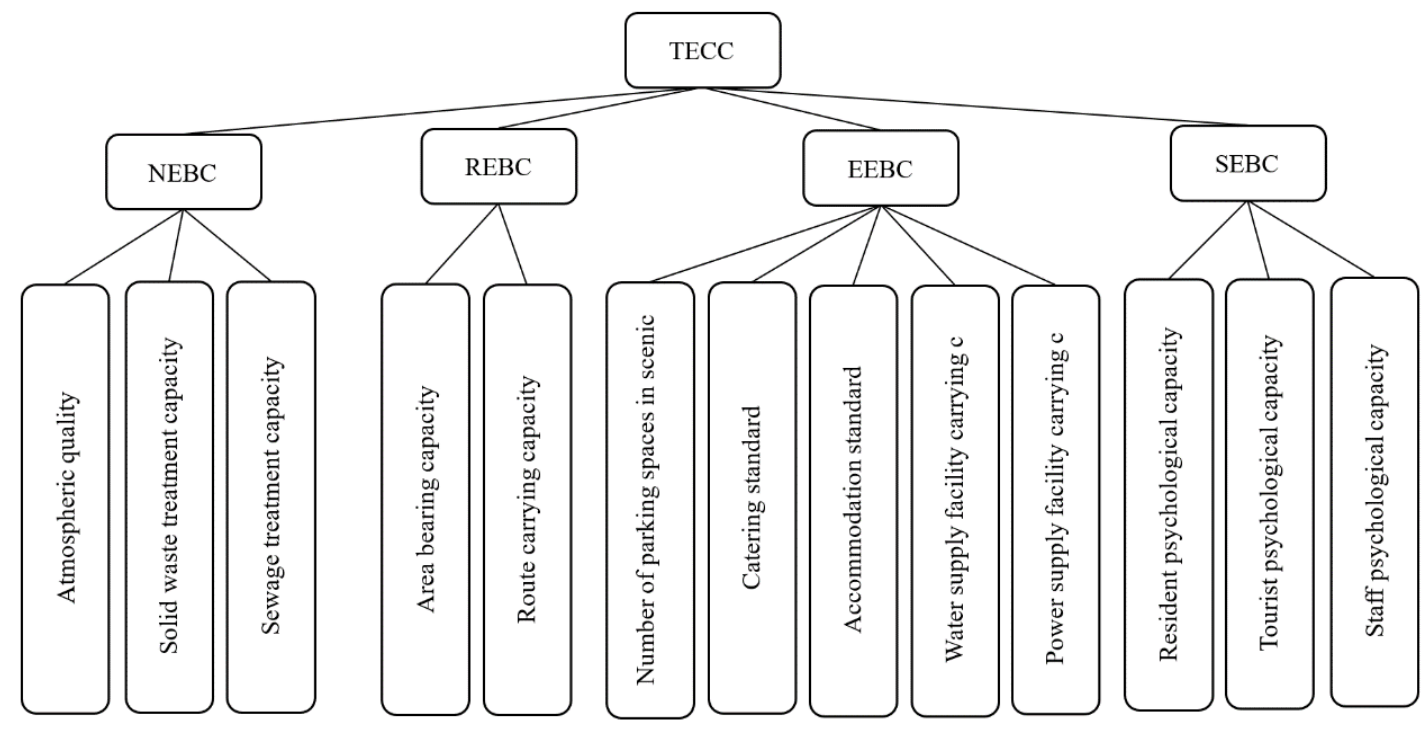

Figure 2. TECC evaluation index system for the DNFP 
Table 2. Judgment matrix

\begin{tabular}{lllll}
\hline EEBC & REBC & EEBC & SEBC & NEBC \\
\hline $\mathrm{Wi}$ & 0.2427 & 0.1439 & 0.1025 & 0.5109 \\
\hline
\end{tabular}

Table 3. Weights of the criteria layer

\begin{tabular}{ccccc}
\hline Criteria & REBC & EEBC & SEBC & NEBC \\
\hline REBC & 1 & 2 & 3 & $1 / 3$ \\
EEBC & $1 / 2$ & 1 & 2 & $1 / 4$ \\
SEBC & $1 / 3$ & $1 / 2$ & 1 & $1 / 3$ \\
NEBC & 3 & 4 & 3 & 1 \\
\hline
\end{tabular}

Table 4. Statistics on the number of tourists and ticket revenue of the DNFP in 2012-2018

\begin{tabular}{ccc}
\hline Year & Number of tourists & $\begin{array}{c}\text { Ticket revenue } \\
\text { (RMB 10,000 yuan) }\end{array}$ \\
\hline 2012 & 20,000 & 180 \\
2013 & 12,000 & 136 \\
2014 & 15,000 & 172 \\
2015 & 18,000 & 150 \\
2016 & 28,000 & 238 \\
2017 & 36,800 & 298 \\
2018 & 45,700 & 349 \\
Mean & 25,071 & 217 \\
\hline
\end{tabular}

The above evaluation shows that the DNFP has a strong TECC, and offers a rare and valuable tourism resource in Changchun: ice and karst caves. Besides attracting tourists through internal improvement, the scenic spot should fully integrate to the planned Changchun Economic Circle, and prepare a development strategy for scenic spot-driven rural tourism, which promotes the mutual growths of the scenic spot and the nearby villages [30].

\section{RURAL REVITALIZATION THROUGH SCENIC SPOT-DRIVEN RURAL TOURISM}

\subsection{Current situation}

Treating the scenic spot as the driving engine, the scenic spot-driven rural tourism aims to promote rural tourism activities based on the tourists attracted by the scenic spot and the unique advantageous resources of nearby villages [31].

The DNFP enjoys a strong attractiveness in Changchun. From downtown Changchun to the scenic spots, there are six administrative villages. The location advantage of Changchun lays a good foundation for the development of rural tourism in these suburban villages. Relying on the popularity of the scenic spot, the villages are natural gathering places for tourists. It is possible for them share the tourists with the scenic spot, and provide services not available in the scenic spot.

The rural customs and ecological landscapes in the nearby villages change progressively from those in the scenic spot. In these villages, the dominant landscapes are cultural and pastoral, which compensate for and complement the weak functions (e.g. recreation and amusement) of the scenic spot.

The local government has long been concerned with rural revitalization. Rural tourism is the key path towards rural revitalization. The development of rural tourism could effectively lift the poor villagers out of poverty [32]. Currently, the rural tourism under the radiation of the scenic spot has just started. The local practitioners of rural tourism are mostly the elderly, women, and children.

At this stage, the scenic spot should, in addition to pursuing profits, handle the relationship between its development and the poor population in nearby villages. During the development, the scenic spot is obliged to enable nearby villagers to benefit from rural tourism. Nevertheless, the local government has not prepared a good strategy for scenic spotdriven rural tourism.

\subsection{Problems and solutions}

(1) Lack of integration between scenic spot and nearby villages

Compared with similar scenic spots, the DNFP has not implemented unified planning and coordinated development with the rural tourism in nearby villages. The scenic spot and nearby villages have been developing separately, failing to achieve synergistic effect. The villagers have not benefited from the development of the scenic spot, and remained impoverished. Therefore, the resident psychological capacity is rather weak, which indirectly dampens the tourist experience.

To solve the problem, the DNFP could change itself into a semi-open scenic spot. For example, the ticket office could be relocated to the entrance of a nearby village. After buying the ticket, the tourists could move freely in the village and the scenic spot. The through ticket mechanism encourages tourists to spend more money, creating a new income channel for the villagers. Besides, the scenic spot and nearby villages are integrated spatially into a symbiont. Meanwhile, the nearby villages need to establish rural tourism management committees to fully consider the services provided by rural tourism facilities and the scenic spot, and optimize the spatial structure into that of a tourism-based comprehensive community, giving full play to the synergy between villages and the scenic spot.

(2) Lack of a rational income distribution system between scenic spot and nearby villages

According to the stakeholder theory, the employees of the scenic spot and the nearby villagers engaged in rural tourism are both stakeholders. However, the scenic spot might maximize their interests at the cost of those of villagers. For instance, the development of scenic spot has damaged the ecoenvironment; the malicious competition between the scenic spot and rural tourism has caused property losses of villagers, because they have much fewer capital than the scenic spot. The irrational distribution of income hurts the interests of villagers, and bottlenecks the development of rural tourism.

To solve the problem, the government has the obligation to make interventions. For example, the villagers whose land is acquired should be compensated for reasonably. The villagers engaged in rural tourism should be provided with low-interest loans. Furthermore, the relationship between scenic spot and villagers should be coordinated, and a reasonable income distribution system should be created to benefit the villagers in the development of rural tourism.

(3) Lack of talents for scenic spot-based rural tourism

Under the tide of economic growth, many villagers choose to serve as migrant workers in cities. The local practitioners of rural tourism are mostly the elderly, women, and children, providing lodging and dining services to agritainment tourists. 
Many of them lack professional skills and have poor literacy. It is difficult for them to give tourists a good travel experience. This indirectly hinders the development of scenic spot-based rural tourism.

To solve the problem, the scenic spot should organize regular skill trainings, and guide villagers to learn autonomously, turning them into frontline employees of rural tourism. In this way, the villagers will know how to improve themselves and get out of poverty. Moreover, the scenic spot should publicize the inevitable trend and bright prospect of rural tourism to the villagers, improve the economic conditions of the nearby villages, and encourage the non-agricultural villagers to participate in rural tourism.

\section{(4) Lack of government guidance on rural tourism}

The local government has not guided stakeholders to actively participate in rural tourism. As a result, the villagers are not clear about rural tourism, adding to the difficulty in implementing tourism activities. In fact, the local government has not recognized the importance of rural tourism, but solely focused the development of the scenic spot. What is worse, the scattered villagers engaged in rural tourism have not been managed in a centralized manner. Most of them find it hard to make money. Under this background, it is difficult to revitalize the rural areas through tourism.

To solve the problem, the government should publicize rural tourism of the villages on news and online, attracting tourists to these villages, and create a good development platform for the scenic spot and the villages. The government must also create and spread DNFP-centered rural tourism brands with local features, and optimize the policies for inviting outside investments on local infrastructure. In addition, the government should implement centralized management of the scattered villagers engaged in rural tourism. For example, the government could establish a rural tourism development office to set goals for practitioners, promote green industrial development, and maximize the value of tourism development.

\section{CONCLUSIONS}

This paper quantifies the TECC of the DNFP on yaaph software, and evaluates the current status of rural tourism near the scenic spot. The main conclusions are as follows:

(1) The scenic spot-based rural tourism is a desirable way to further develop tourism and satisfy the growing tourist activities within Jilin province, laying the basis for sustainable development of rural tourism resources.

(2) Four criteria were selected according to the actual situation of the scenic spot. The TECC of the DNFP was calculated as 6,160 persons. Besides, the annual TECC of the scenic spot equals $160 * 6,160=985,600$ (person/year). From 2012 to 2018 , the scenic spot received 25,071 persons each year, indicating that the scenic spot is under weak load.

(3) Currently, the rural tourism in villages around the DNFP has just started. The scale of rural tourism is rather limited, owing to the lack of good infrastructure, sufficient publicity, and government guidance.

To sum up, the scenic spot-based rural tourism offers a poverty alleviation model rooted in regional economic growth. This model aims to forge an industrial chain that benefits both the scenic spot and nearby villages, and improve the income and life quality of villagers. According to the TECC and development status of the DNFP, Changchun should optimize the design and implementation of DNFP-based rural tourism from four aspects: enhancing the integration between scenic spot and nearby villages, rationalizing the income distribution system, training talents for scenic spot-based rural tourism, and stepping up government guidance on rural tourism. These measures can improve the income and life quality of villagers, promote the healthy development between the scenic spot and nearby villages, and speed up the realization of poverty alleviation.

\section{ACKNOWLEDGMENT}

This work is supported by Jilin Provincial Social Sciences Foundation, as part of the program Effect Analysis and Path Optimization of Tourism Poverty Alleviation in Jilin Province in the Context of Rural Revitalization (Grant No.: 2018B95).

\section{REFERENCES}

[1] Llausàsa, A., Vila-Subirós, J., Pueyo-Rosb, J., Fraguell, R.M. (2019). Carrying capacity as a tourism management strategy in a marine protected area. Conservation \& Society, 17(4): 366-376. https://doi.org/10.4103/cs.cs_18_154

[2] Salemi, M., Jozi, S.A., Malmasi, S., Rezaian, S. (2019). Conceptual framework for evaluation of ecotourism carrying capacity for sustainable development of Karkheh protected area, Iran. International Journal of Sustainable Development \& World Ecology, 26(4): 354366. https://doi.org/10.1080/13504509.2019.1570379

[3] Vargas-Sánchez, A. (2018). The unavoidable disruption of the circular economy in tourism. Worldwide Hospitality and Tourism Themes, 10(6): 652-661. https://doi.org/10.1108/WHATT-08-2018-0056

[4] Corbau, C., Benedetto, G., Congiatu, P.P., Simeoni, U., Carboni, D. (2019). Tourism analysis at Asinara Island (Italy): Carrying capacity and web evaluations in two pocket beaches. Ocean \& Coastal Management, 169: 2736. https://doi.org/10.1016/j.ocecoaman.2018.12.004

[5] Matijová, M., Onuferová, E., Rigelský, M., Stanko, V. (2019). Impact of selected indicators of tourism capacity and performance in the context of the unemployment rate in slovakia. Journal of Tourism and Services, 10(19): 123. https://doi.org/10.29036/jots.v10i19.95

[6] Zhu, J., Wang, E., Sun, W. (2019). Application of monte carlo AHP in ranking coastal tourism environmental carrying capacity factors. Asia Pacific Journal of Tourism Research, 24(7): 644-657. https://doi.org/10.1080/10941665.2019.1611610

[7] Triyatmo, B., Rustadi, P.S., Priyono, S. (2018). Characteristics and environmental carrying capacities of coastal area in Yogyakarta Special Region for aquaculture. In Proceeding of The 2nd International Symposium on Marine and Fisheries Research 2017. IOP Conference Series: Earth and Environmental Science, 139: $\quad 012007 . \quad$ https://doi.org/10.1088/17551315/139/1/012007/meta

[8] Lerario, A., Di Turi, S. (2018). Sustainable urban tourism: Reflections on the need for building-related indicators. Sustainability, $\quad 10(6)$ : https://doi.org/10.3390/su10061981 
[9] Cupul-Magaña, A.L., Rodríguez-Troncoso, A.P. (2017). Tourist carrying capacity at Islas Marietas National Park: An essential tool to protect the coral community. Applied Geography, 88:

15-23. https://doi.org/10.1016/j.apgeog.2017.08.021

[10] Dvarskas, A. (2017). Dynamically linking economic models to ecological condition for coastal zone management: Application to sustainable tourism planning. Journal of Environmental Management, 188: 163-172. https://doi.org/10.1016/j.jenvman.2016.12.014

[11] Vujko, A., Plavša, J., Petrović, M.D., Radovanović, M., Gajić, T. (2017). Modelling of carrying capacity in National Park-Fruška Gora (Serbia) case study. Open Geosciences, 9(1): 61-72. https://doi.org/10.1515/geo2017-0005

[12] Cisneros, M.A.H., Sarmiento, N.V.R., Delrieux, C.A., Piccolo, M.C., Perillo, G.M. (2016). Beach carrying capacity assessment through image processing tools for coastal management. Ocean \& Coastal Management, 130: $138-147$. https://doi.org/10.1016/j.ocecoaman.2016.06.010

[13] Lwoga, N.B., Maturo, E. (2020). Motivation-based segmentation of rural tourism market in African villages. Development Southern Africa, 1-18. https://doi.org/10.1080/0376835X.2020.1760791

[14] Silva-Pérez, V., De Faveri, J., Molero, G., Deery, D.M., Condon, A.G., Reynolds, M.P., Furbank, R.T. (2020). Genetic variation for photosynthetic capacity and efficiency in spring wheat. Journal of Experimental Botany, 71(7): 2299-2311. https://doi.org/10.1093/jxb/erz439

[15] Buckley, R. (2020). Nature tourism and mental health: parks, happiness, and causation. Journal of Sustainable Tourism, 28(9): 1409-1424 https://doi.org/10.1080/09669582.2020.1742725

[16] Raftopoulos, M. (2020). Rural community - based tourism and its impact on ecological consciousness, environmental stewardship and social structures. Bulletin of Latin American Research, 39(2): 142-156. https://doi.org/10.1111/blar.12749

[17] Smith, M.J. (2020). Sustainable development goals: genuine global change requires genuine measures of efficacy. Journal of Maps, 16(1). https://doi.org/10.1080/17445647.2020.1749385

[18] Kulusjärvi, O. (2019). Towards just production of tourism space via dialogical everyday politics in destination communities. Environment and Planning C: Politics and Space, 2399654419887964. https://doi.org/10.1177/2399654419887964

[19] Becken, S., Whittlesea, E., Loehr, J., \& Scott, D. (2020). Tourism and climate change: evaluating the extent of policy integration. Journal of Sustainable Tourism, 28(10):

$1-22$. https://doi.org/10.1080/09669582.2020.1745217

[20] Kaslik, E., Neamţu, M. (2020). Dynamics of a tourism sustainability model with distributed delay. Chaos, Solitons \& Fractals, 133: 109610. https://doi.org/10.1016/j.chaos.2020.109610

[21] Neuts, B., Vanneste, D. (2020). Analysing residential preferences for urban redevelopment in tourism destinations: An application of choice experiments.
Tourism Planning \& Development, 17(2): 147-165. https://doi.org/10.1080/21568316.2019.1580211

[22] Bello, F.G., Kamanga, G. (2020). Drivers and barriers of corporate social responsibility in the tourism industry: The case of Malawi. Development Southern Africa, 37(2): 181-196. https://doi.org/10.1080/0376835X.2018.1555028

[23] Urbis, A., Povilanskas, R., Newton, A. (2019). Valuation of aesthetic ecosystem services of protected coastal dunes and forests. Ocean \& Coastal Management, 179: 104832. https://doi.org/10.1016/j.ocecoaman.2019.104832

[24] Khan, A., Bibi, S., Ardito, L., Lyu, J., Hayat, H., Arif, A.M. (2020). Revisiting the dynamics of tourism, economic growth, and environmental pollutants in the emerging economies-sustainable tourism policy implications. $\quad$ Sustainability, 12(6): 2533. https://doi.org/10.3390/su12062533

[25] Araújo Vila, N., Fraiz Brea, J.A., de Araújo, A.F. (2020). Health and sport. economic and social impact of active tourism. European Journal of Investigation in Health, Psychology and Education, 10(1): 70-81. https://doi.org/10.3390/ejihpe10010007

[26] Martín, R., Yepes, V. (2019). The concept of landscape within marinas: Basis for consideration in the management. Ocean \& Coastal Management, 179: 104815 .

https://doi.org/10.1016/j.ocecoaman.2019.104815

[27] Benitez, J., Lencinas, M.V., Huertas Herrera, A., Martínez Pastur, G. (2019). Assessing the conservation value of nature reserves: Terrestrial birds in Isla de los Estados (Staten Island) Provincial Reserve, Tierra del Fuego, Argentina. Community Ecology, 20(2): 181-193. https://doi.org/10.1556/168.2019.20.2.8

[28] Schirpke, U., Altzinger, A., Leitinger, G., Tasser, E. (2019). Change from agricultural to touristic use: Effects on the aesthetic value of landscapes over the last 150 years. Landscape and Urban Planning, 187: 23-35. https://doi.org/10.1016/j.landurbplan.2019.03.004

[29] Schweickert, R.A., Moore, J.G., Lahren, M.M., Kortemeier, W., Kitts, C., Adamek, T. (2019). The Tahoe-Sierra frontal fault zone, Emerald Bay area, Lake Tahoe, California: History, displacements, and rates. Geosphere, $\quad 15(3)$ : https://doi.org/10.1130/GES02022.1

[30] Woo, K.S., Kim, L., Ji, H., Jeon, Y., Ryu, C.G., Wood, C. (2019). Geological heritage values of the Yongcheon Cave (Lava Tube Cave), Jeju Island, Korea. Geoheritage, 11(2): 615-628. https://doi.org/10.1007/s12371-0180315-y

[31] Jeong, T., Park, S.W., Lee, S. (2019). A comparative study on the value of scenic views between an inland and a coastal city in Korea. Pacific Rim Property Research Journal, 25(2): 101-124. https://doi.org/10.1080/14445921.2019.1610595

[32] Alazaizeh, M.M., Hallo, J.C., Backman, S.J., Norman, W.C., Vogel, M.A. (2019). Giving voice to heritage tourists: indicators of quality for a sustainable heritage experience at Petra, Jordan. Journal of Tourism and Cultural Change, 17(3): 269-284. https://doi.org/10.1080/14766825.2018.1455693 